\title{
KARAKTERISTIK MEKANIS DAN PERILAKU LENTUR BALOK KAYU LAMINASI MEKANIK
}

\author{
Ratna Prasetyowati Putri \\ Alumni Dept. Teknologi Hasil Hutan, IPB \\ ratnathh@gmail.com
}

Fengky Satria Yoresta

Divisi Rekayasa dan Desain Bangunan Kayu, Dept. Teknologi Hasil Hutan, IPB

syfengky@gmail.com

\begin{abstract}
Abstrak
Penggunaan paku atau baut maupun kombinasinya dengan perekat sebagai penghubung antar lamina pada balok kayu laminasi akan mempengaruhi karakteristik mekanis dan perilaku keruntuhan balok tersebut. Penelitian ini bertujuan menentukan karakteristik mekanis dan menganalisa perilaku lentur balok kayu laminasi mekanik. Tiga tipe balok laminasi digunakan dalam penelitian ini, ditambah balok glulam sebagai kontrol. Balok tipe 1 menggunakan baut/paku di sepanjang bentang sebagai penghubung antar lamina. Balok tipe 2 hanya menggunakan paku/baut pada sepertiga bentang di kedua ujung balok, sedangkan pada sepertiga bentang lainnya menggunakan perekat. Paku atau baut pada balok tipe 3 ditempatkan pada sepertiga bentang di tengah balok dan sisanya menggunakan perekat. Pengujian lentur dilakukan dengan metode one point centre loading dengan jarak antar tumpuan $90 \mathrm{~cm}$. Hasil penelitian menyimpulkan balok tipe 3 memiliki nilai Modulus Elastisitas (MOE) tertinggi dibandingkan balok tipe 1 dan tipe 2. MOE balok laminasi tertinggi terdapat pada balok laminasi-paku diameter $0.3 \mathrm{~cm}$ tipe $3\left(52162.95 \mathrm{~kg} / \mathrm{cm}^{2}\right)$ sedangkan terendah pada balok laminasi-paku diameter $0.3 \mathrm{~cm}$ tipe $1\left(11077.41 \mathrm{~kg} / \mathrm{cm}^{2}\right)$. Modulus of Rupture (MOR) tertinggi terdapat pada balok laminasi-paku diameter 0.3 tipe 3 $\left(368.16 \mathrm{~kg} / \mathrm{cm}^{2}\right)$ dan terendah pada balok laminasi-baut diameter $0.5 \mathrm{~cm}$ tipe $3(207.36$ $\mathrm{kg} / \mathrm{cm}^{2}$ ). Balok kontrol memiliki nilai MOE dan MOR tertinggi dibandingkan semua balok laminasi mekanik. Posisi penempatan baut, paku, dan perekat pada balok laminasi hanya berpengaruh terhadap nilai MOE. Semua kerusakan yang ditemukan pada balok laminasi mekanik adalah berupa kerusakan lentur dan geser antar lamina.
\end{abstract}

Kata kunci: balok, glulam, laminasi mekanik, pengujian lentur

\begin{abstract}
The use of nails or bolts or its combination with adhesive as connector between lamina on laminated wood beams will affect the mechanical characteristics and collapse behavior of the beam. This study aims to determine the mechanical characteristics and analyze the flexural behavior of mechanical-laminated wood beams. Three types of the mechanicallaminated beams used in this study beside glulam beams as control. The type 1 using bolts/nails along the span as a connector between laminas. Beam type 2 only using nails/bolts on the one-third span at both ends of the beam, while adhesive on the other space of span. Nails or bolts on beam type 3 is placed on the one-third span at the middle of the beam, and the other space using adhesive. Bending test was conducted by using one-point centre loading method with $90 \mathrm{~cm}$ of span. The study concluded that beam type 3 has the highest value of Modulus of Elasticity (MOE) compared to beam type 1 and type 2. The highest MOE for laminated beams is found on nail-laminated beam with diameter of $0.3 \mathrm{~cm}$
\end{abstract}


type $3\left(52162.95 \mathrm{~kg} / \mathrm{cm}^{2}\right)$ while the lowest one is on nail-laminated beam with diameter of 0.3 cm type $1\left(11077.41 \mathrm{~kg} / \mathrm{cm}^{2}\right)$. The highest Modulus of Rupture (MOR) is found on naillaminated beam with diameter of $0.3 \mathrm{~cm}$ type $3\left(368.16 \mathrm{~kg} / \mathrm{cm}^{2}\right)$, and the lowest one is on bolt-laminated beam with diameter of $0.5 \mathrm{~cm}$ type $3\left(207.36 \mathrm{~kg} / \mathrm{cm}^{2}\right)$. The control beam has the highest value of MOE and MOR compared to all mechanical-laminated wood beams. Position of bolts, nails, and adhesive on the laminated beams is only affects to MOE. All damage found on the mechanical-laminated beams is in form of flexural collapse and shear failure among laminas.

Keywords: beams, glulam, mechanical-laminated, flexural test

\section{Pendahuluan}

Penggunaan kayu sebagai bahan konstruksi sampai saat ini masih menjadi pilihan masyarakat Indonesia. Sebagai bahan konstruksi maka diperlukan kayu dengan dimensi (panjang dan lebar) yang besar serta kuat. Kayu dengan kualitas tersebut biasanya didapatkan dari hutan alam. Namun perlu diketahui, pasokan kayu dari hutan alam menurun sehingga diperlukan solusi untuk mengatasi pasokan kayu yang terbatas tersebut. Alternatif untuk mengatasi kekurangan kayu dari hutan alam adalah menggunakan kayu dari hutan rakyat (HR). Mahoni merupakan salah satu kayu hutan rakyat yang memiliki kelas kuat II-III (P3HH 2008). Namun kayu yang dijual di pasaran memiliki dimensi (panjang dan lebar) yang terbatas, sehingga diperlukan suatu produk rekayasa agar membuat kayu ini memiliki dimensi yang besar. Produk rekayasa tersebut adalah balok laminasi.

Balok laminasi (Glulam Beam) merupakan produk rekayasa yang terdiri dari dua atau lebih lapisan kayu (lamina) yang saling direkat dalam arah serat longitudinal (Moody et al. 1999). Balok laminasi memiliki beberapa keunggulan dibandingkan dengan kayu solid diantaranya adalah dapat dibuat dari kayu dengan log berdiameter kecil dan berkualitas rendah, penampang dan panjang balok dapat dibuat lebih besar dan panjang sesuai kebutuhan, serta dapat dibuat melengkung. Balok laminasi lebih efisien jika dibandingkan dengan kayu solid karena dapat dibuat dalam berbagai variasi bentuk, jumlah lapisan, dan ukuran sehingga dapat menghasilkan ukuran yang besar. Selain menggunakan perekat, balok laminasi juga dapat menggunakan paku atau baut maupun kombinasi antara perekat dengan baut atau paku sebagai penghubung antar laminanya. Balok jenis ini dikenal dengan balok laminasi mekanik.

Penggunaan kombinasi antara perekat dan paku atau baut sebagai penghubung antar lamina serta penempatannya akan mempengaruhi karakteristik mekanis dan perilaku keruntuhan balok. Penelitian mengenai perilaku keruntuhan balok kayu laminasi-mekanik belum banyak dikembangkan di Indonesia. Oleh karena itu, penelitian ini perlu dilakukan untuk lebih memahami karakteristik dan perilaku keruntuhan balok laminasi-mekanik paku dan baut.

Penelitian ini bertujuan untuk menentukan karakteristik mekanis dan menganalisis perilaku lentur balok kayu laminasi-mekanik. Hasil penelitian ini diharapkan dapat memberikan informasi dan data mengenai karakteristik balok kayu laminasi-mekanik yang menggunakan paku dan baut sebagai alat sambung untuk perkembangan konstruksi kayu.

\section{Metode Penelitian}

Penelitian ini menggunakan kayu mahoni (Swietenia macrophylla King) yang berasal dari lokasi penggergajian kayu Jasinga Bogor. Alat sambung yang digunakan berupa perekat epoxy extreme demp-x (Tabel 1), baut diameter $0.3 \mathrm{~cm}$ dan $0.5 \mathrm{~cm}$, dan paku diameter $0.3 \mathrm{~cm}$ dan $0.5 \mathrm{~cm}$. 
Tabel 1. Data sifat perekat epoxy extreme demp-x

\begin{tabular}{ll}
\hline \multicolumn{1}{c}{ Pengujian perekat } & \multicolumn{1}{c}{ Hasil pengujian } \\
\hline Kenampakan & Warna putih, halus, tidak ada debu, lengket, \\
& sangat kental, dan bau tidak terlalu menyengat \\
Keasaman atau pH & 11 \\
Kekentalan & Lebih dari 200 poise \\
Berat jenis & 1.69 \\
Sisa penguapan & $98.91 \%$ \\
Kadar abu & $96.56 \%$ \\
Waktu gelatinasi & 7 menit \\
\hline
\end{tabular}

Semua balok dipersiapkan untuk pengujian lentur dengan dimensi $5 \mathrm{~cm}$ x $5 \mathrm{~cm}$ x 100 $\mathrm{cm}$. Pengujian balok dilakukan melalui pembebanan satu titik di tengah bentang (one point centre loading) dengan panjang bentang $90 \mathrm{~cm}$.

Tiga tipe balok laminasi mekanik dipersiapkan dalam penelitian ini dan ditambah satu balok glulam. Tiga tipe balok laminasi tersebut dibedakan menurut posisi penempatan perekat dan baut atau paku pada daerah geser di sepanjang balok. Gere \& Timoshenko (2000) menyatakan bahwa gaya geser maksimum pada balok sederhana dengan satu beban terpusat terdapat di ujung balok yang terdekat dengan beban terpusat tersebut. Modifikasi alat sambung pada daerah ini akan mempengaruhi karakteristik dan perilaku keruntuhan balok.

Balok tipe 1 menggunakan baut atau paku di sepanjang bentangnya sebagai penghubung antar lamina. Balok tipe 2 dan tipe 3 menggunakan kombinasi paku atau baut dan perekat sebagai penghubung antar lamina. Paku atau baut pada balok tipe 2 ditempatkan pada sepertiga bentang di kedua ujung balok dan perekat pada sepertiga bentang di tengah balok. Paku atau baut untuk balok tipe 3 diletakkan pada sepertiga bentang di bagian tengah balok dan perekat pada sepertiga bentang dikedua ujung balok. Paku atau baut di semua tipe balok tersebut ditempatkan dengan jarak $6 \mathrm{~cm}$. Model balok tersebut diperlihatkan pada Gambar 1.

Semua balok disusun menggunakan tiga lapis lamina dengan ketebalan atas, tengah, dan bawah berturut-turut $1.5 \mathrm{~cm}, 2 \mathrm{~cm}$, dan $1.5 \mathrm{~cm}$. Pada bagian lamina yang ditentukan menggunakan perekat, dilabur perekat epoxy extreme demp-x dengan berat labur $280 \mathrm{~g} / \mathrm{m}^{2}$. Pelaburan perekat pada kayu laminasi ini dilakukan dengan cara double spread. Kayu laminasi kemudian dikempa dingin selama empat jam dengan tekanan spesifik $4.44 \mathrm{~kg} / \mathrm{cm}^{2}$. Pengkondisian kayu dilakukan selama dua minggu dan dilanjutkan dengan pemasangan paku atau baut.

Balok tipe 1, 2, dan 3 masing-masing terdiri dari dua jenis, yaitu balok yang menggunakan paku atau baut dengan diameter $0.3 \mathrm{~cm}$ dan balok yang menggunakan paku atau baut dengan diameter $0.5 \mathrm{~cm}$. Masing-masing jenis balok tersebut terdiri atas tiga contoh uji. Total semua contoh uji berjumlah 39 buah yang terdiri dari balok tipe 1, 2, dan 3 (36 buah) serta balok glulam (3 buah) yang disajikan pada Tabel 2. 


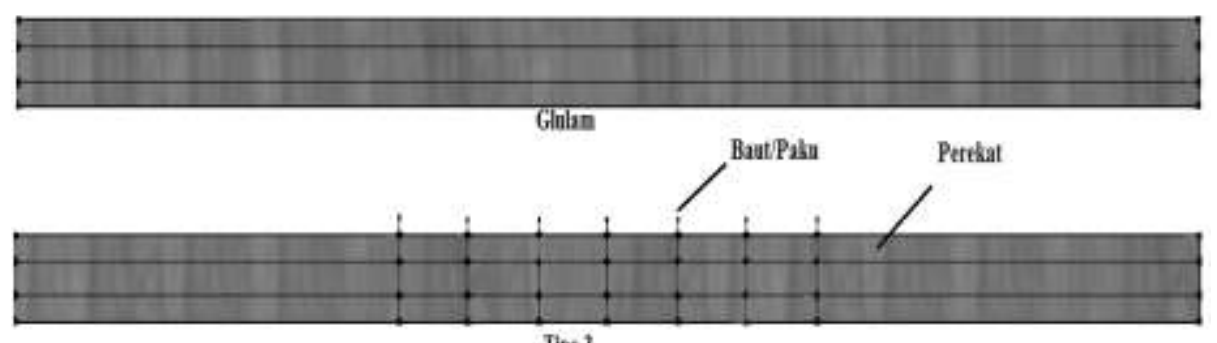

Tipe 3

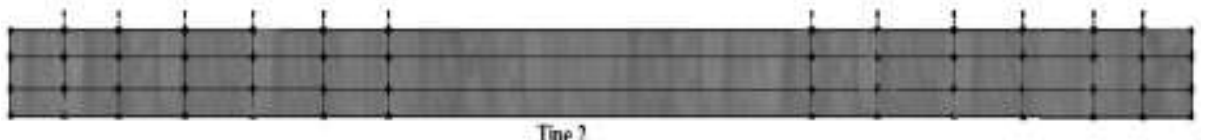

Tipe ?
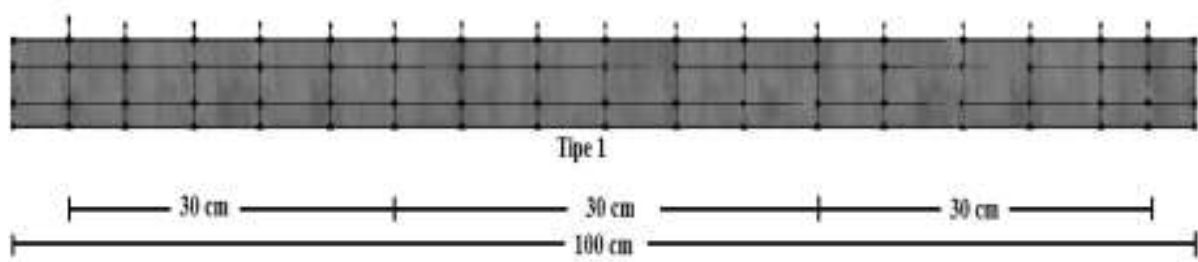

Gambar 1. Tipe balok laminasi

Sumber: Ilustrasi metode

Tabel 2. Kode dan jumlah contoh uji

\begin{tabular}{|c|c|c|c|c|}
\hline Alat sambung & $\begin{array}{l}\text { Diameter alat } \\
\text { sambung }\end{array}$ & Balok & Kode contoh uji & Jumlah \\
\hline \multirow{6}{*}{ Paku } & \multirow{3}{*}{$0.3 \mathrm{~cm}$} & Tipe 1 & PA1 & 3 \\
\hline & & Tipe 2 & PA2 & 3 \\
\hline & & Tipe 3 & $\mathrm{PA} 3$ & 3 \\
\hline & \multirow{3}{*}{$0.5 \mathrm{~cm}$} & Tipe 1 & $\mathrm{~PB} 1$ & 3 \\
\hline & & Tipe 2 & PB2 & 3 \\
\hline & & Tipe 3 & PB3 & 3 \\
\hline \multirow{6}{*}{ Baut } & \multirow{3}{*}{$0.3 \mathrm{~cm}$} & Tipe 1 & BA1 & 3 \\
\hline & & Tipe 2 & BA2 & 3 \\
\hline & & Tipe 3 & $\mathrm{BA} 3$ & 3 \\
\hline & \multirow{3}{*}{$0.5 \mathrm{~cm}$} & Tipe 1 & BB1 & 3 \\
\hline & & Tipe 2 & BB2 & 3 \\
\hline & & Tipe 3 & BB3 & 3 \\
\hline \multirow[t]{2}{*}{ Glulam } & \multicolumn{2}{|c|}{ Perekat epoxy extreme demp-x } & Glulam & 3 \\
\hline & \multicolumn{2}{|c|}{ TOTAL } & & 39 \\
\hline
\end{tabular}




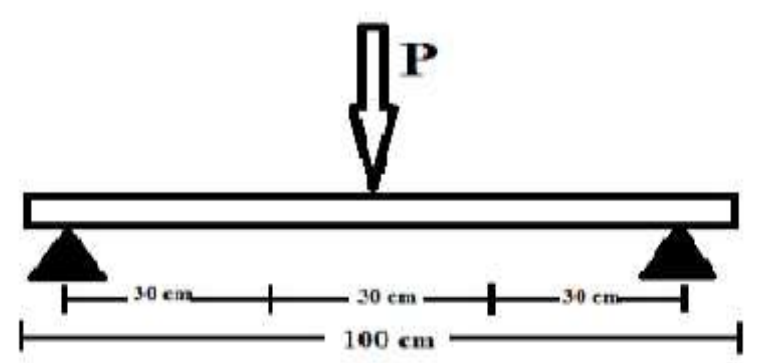

Gambar 2. Skema pengujian lentur balok laminasi Sumber: Ilustrasi metode

Balok laminasi diuji lentur dengan metode pembebanan terpusat di tengah bentang (one point centre loading) dengan jarak antar tumpuan adalah $90 \mathrm{~cm}$. Kadar air kayu saat pengujian balok adalah 12.69\%. Skema pengujian diperlihatkan pada Gambar 2. Modulus of Elasticity (MOE) dan Modulus of Rupture (MOR) ditentukan menggunakan persamaan berikut,

$$
\operatorname{MOE}\left(\mathrm{kg} / \mathrm{cm}^{2}\right)=\frac{\Delta \mathrm{PL}^{3}}{4 \Delta \mathrm{Ybh}^{3}}
$$

$\operatorname{MOR}\left(\mathrm{kg} / \mathrm{cm}^{2}\right)=\frac{3 \mathrm{PL}}{2 \mathrm{bh}^{2}}$

dimana $\Delta \mathrm{P}$ adalah perubahan beban sebelum batas proporsi $(\mathrm{kg}), \mathrm{L}$ adalah jarak dua tumpuan $(\mathrm{cm}), \Delta \mathrm{Y}$ adalah perubahan defleksi akibat perubahan beban $(\mathrm{cm}), \mathrm{b}$ dan $\mathrm{h}$ masing-masing adalah lebar dan tebal contoh uji $(\mathrm{cm})$, dan $\mathrm{P}$ adalah beban maksimum $(\mathrm{kg})$.

Data hasil pengujian diolah menggunakan program Microsoft Excel 2013 dan ditampilkan dalam bentuk tabel dan grafik. Rancangan percobaan menggunakan rancangan acak tersarang dengan faktor utama tipe balok, sedangkan jenis alat sambung tersarang pada tipe balok dan diameter alat sambung tersarang pada jenis alat sambung. Data MOE dan MOR dianalisis secara statistik dengan uji ANOVA dengan tingkat minimal signifikasi $\alpha<0.05$ dan untuk mengetahui faktor-faktor yang berpengaruh nyata dilakukan uji lanjut dengan menggunakan Uji Duncan.

\section{Hasil dan Pembahasan Modulus of Elasticity (MOE)}

MOE adalah nilai indikator untuk kekakuan bahan (kayu) yang hanya berlaku sampai batas proporsi saja (Mardikanto et al. 2011). Data pengujian MOE yang disajikan pada Gambar 3 menunjukkan balok glulam mahoni memiliki rata-rata nilai MOE sebesar 52298.58 $\mathrm{kg} / \mathrm{cm}^{2}$. Pada balok laminasi-mekanik rata-rata nilai MOE terbesar terdapat pada balok PA3 yaitu $52162.95 \mathrm{~kg} / \mathrm{cm}^{2}$. Besarnya rata-rata nilai MOE balok PA3 dibandingkan dengan semua balok laminasi-mekanik menunjukkan bahwa kekakuan balok tersebut lebih tinggi dibandingkan balok laminasi-mekanik lainnya, sehingga kombinasi penempatan perekat pada sepertiga ujung bentang dengan penempatan paku diameter $0.3 \mathrm{~cm}$ di sepertiga tengah bentang balok membuat balok tidak mudah berubah bentuk akibat pembebanan yang diberikan.

Mengacu pada JAS 234:2003 mengenai nilai MOE minimum untuk kayu konstruksi adalah $75000 \mathrm{~kg} / \mathrm{cm}^{2}$, sehingga semua balok laminasi-mekanik dan glulam tidak memenuhi nilai minimum tersebut. Rendahnya nilai MOE pada balok glulam, balok tipe 2, dan tipe 3 dapat disebabkan karena lepasnya ikatan garis rekat antar lamina saat pengujian akibat pengempaan yang terlalu rendah. Anshari (2006) menyatakan bahwa tekanan kempa 
optimum dapat menghasilkan kekuatan lentur maksimum pada balok kayu laminasi. Pengempaan yang terlalu rendah dapat menyebabkan cacat perekatan seperti melepuh, garis perekat yang tebal, dan pecah muka. Rendahnya nilai MOE balok tipe 1 disebabkan karena pada balok laminasi-paku atau balok laminasi-baut disambung pada titik-titik dan bukan pada bidang-bidang seperti sambungan perekat. Yap (1999) menyatakan bahwa efisiensi pada sambungan baut sebesar 30\% dan sambungan paku sebesar 50\%.

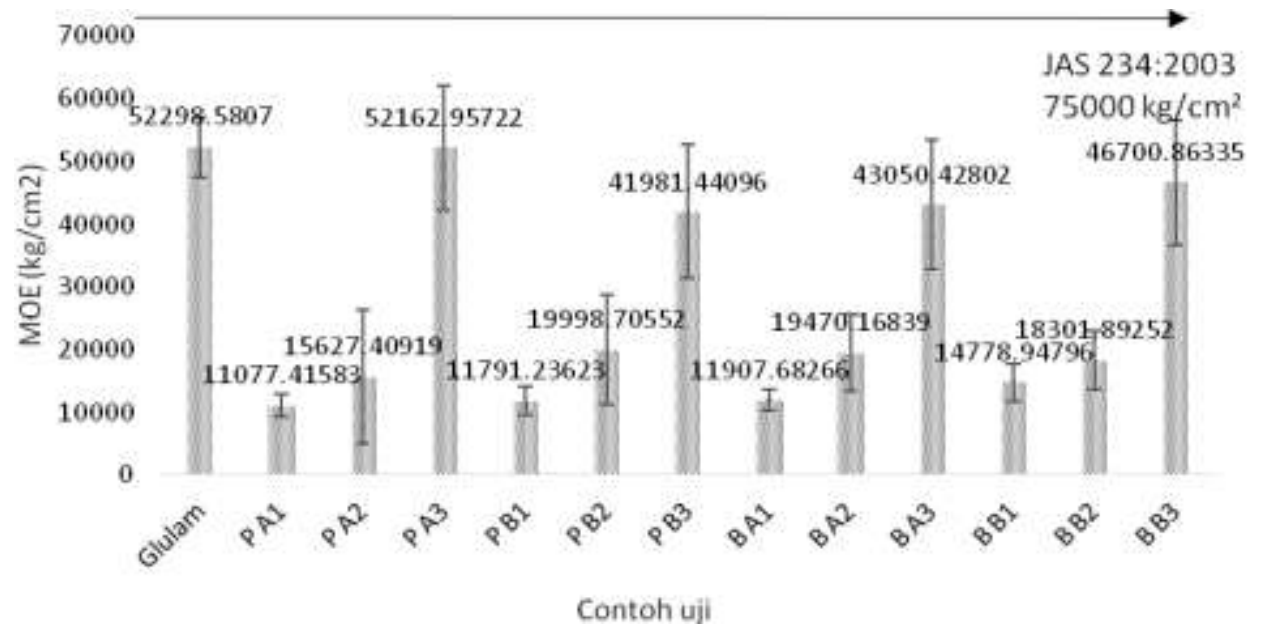

Gambar 3. Nilai MOE balok laminasi-mekanik Sumber: Hasil percobaan/penelitian

Gambar 3 menunjukkan nilai MOE balok laminasi mekanik memperlihatkan pola yang sama pada ketiga tipe balok baik untuk sambungan paku ataupun baut. Balok tipe 3 memiliki nilai yang paling tinggi diikuti oleh balok tipe 2, sedangkan nilai terendah terdapat pada balok tipe 1 . Balok PA3 memiliki nilai rata-rata yang tinggi diantara semua balok laminasi-mekanik sebesar $52162.95 \mathrm{~kg} / \mathrm{cm}^{2}$. Nilai MOE terendah terdapat pada balok PA1 yaitu $11077.41 \mathrm{~kg} / \mathrm{cm}^{2}$.

Besarnya nilai MOE yang dimiliki oleh balok tipe 3 menunjukkan bahwa perekat lebih kuat menahan geser dibandingkan dengan paku atau baut. Balok sederhana dengan satu beban terpusat, gaya geser maksimum terjadi di ujung balok yang terdekat dengan beban terpusat tersebut (Gere dan Timoshenko 2000). Posisi gaya geser pada balok dua tumpuan dengan beban terpusat di tengah bentang akibat beban diperlihatkan pada diagram gaya geser pada Gambar 4.

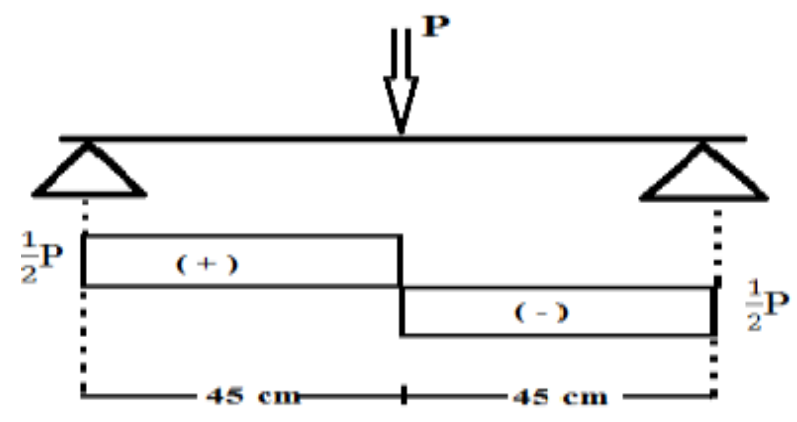

Gambar 4. Diagram gaya geser

Sumber: Hasil percobaan/penelitian 
Hasil analisis anova menunjukkan tipe balok berpengaruh nyata $(\mathrm{P}<0.05)$ terhadap nilai MOE, untuk jenis alat sambung yang tersarang pada tipe dan diameter alat sambung yang tersarang pada jenis alat sambung tidak berpengaruh nyata $(\mathrm{P}>0.05)$. Hasil uji lanjut Duncan diketahui bahwa balok laminasi-mekanik tipe 1 dan tipe 2 tidak berbeda nyata, namun balok tipe 3 berbeda nyata dengan balok tipe 1 dan tipe 2 . Hal ini menunjukkan bahwa penempatan posisi baut, paku atau perekat mempengaruhi kekakuan balok laminasi-mekanik.

\section{Modulus of Rupture (MOR)}

Modulus of Rupture (MOR) merupakan tegangan lentur maksimum balok. Kekuatan lentur menggambarkan kapasitas beban maksimum yang dapat diterima oleh kayu tersebut. Nilai yang menggambarkan kekuatan ini, dihitung berdasarkan rumus dimana berlaku sampai batas proporsi (Mardikanto et al. 2011).

Nilai rata-rata MOR semua balok uji disajikan dalam Gambar 5. Balok laminasi PA3 memiliki nilai rata-rata MOR tertinggi sebesar $368.16 \mathrm{~kg} / \mathrm{cm}^{2}$ jika dibandingkan dengan semua balok laminasi-mekanik. Hal ini menunjukkan balok PA3 mampu menahan kapasitas beban lebih tinggi jika dibandingkan dengan semua balok laminasi-mekanik. Hasil pengujian rata-rata nilai MOR balok glulam sebesar $341.05 \mathrm{~kg} / \mathrm{cm}^{2}$. Mengacu pada JAS 234:2003 bahwa nilai MOR minimum untuk kayu konstruksi adalah $300 \mathrm{~kg} / \mathrm{cm}^{2}$, maka hanya balok glulam, balok PA3, dn balok BA2 yang memenuhi standar.

Gambar 5 menunjukkan nilai MOR semua balok laminasi-mekanik berdasarkan diameter alat sambung memperlihatkan pola yang sama. Balok laminasi-mekanik dengan diameter alat sambung $0.3 \mathrm{~cm}$ memiliki nilai rata-rata MOR yang lebih besar dibandingkan balok diameter $0.5 \mathrm{~cm}$. Hal ini diduga karena paku dengan diameter besar akan membuat lubang yang besar juga sehingga menyebabkan kekuatan sambungan menurun. Hasil penelitian ini sesuai dengan Sadiyo et al. (2011) bahwa pemakaian paku yang terlalu besar sementara kayu yang digunakan memiliki kerapatan rendah, akan terjadi perlemahan akibat banyaknya serat kayu yang terangkat atau terjadi pemadatan kayu.

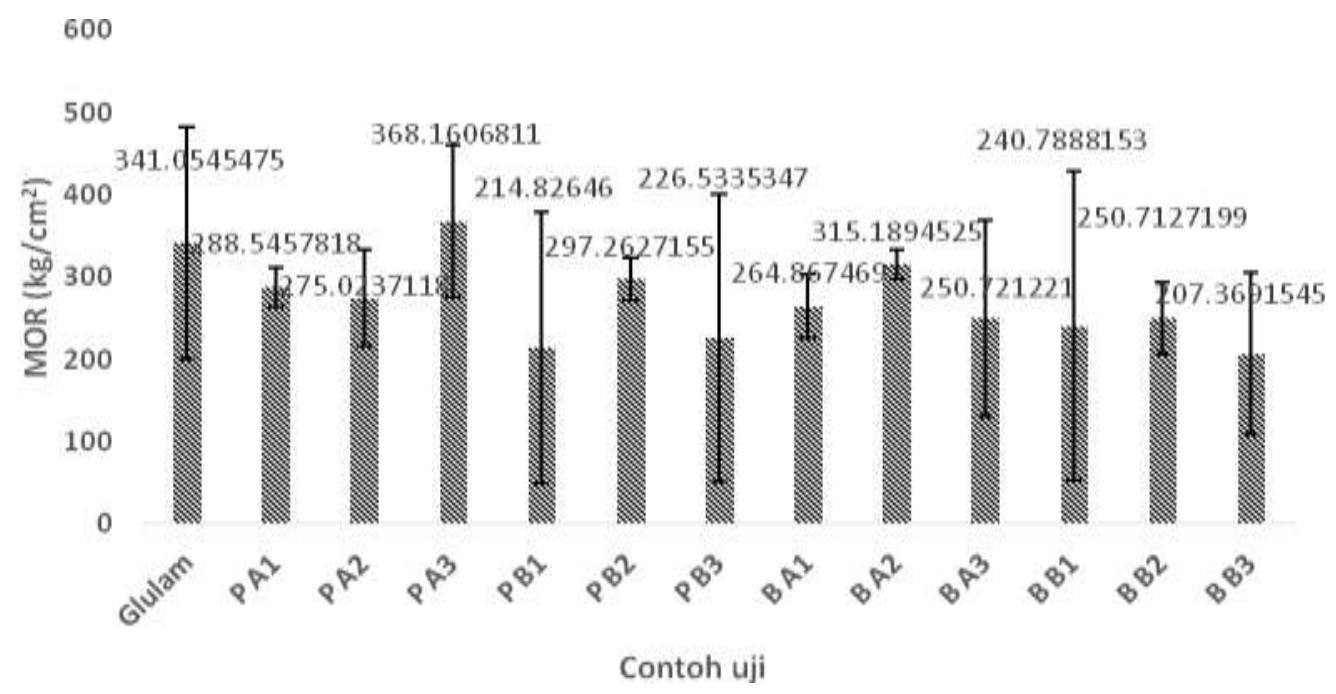

Gambar 5. Nilai MOR balok laminasi-mekanik Sumber: Hasil percobaan/penelitian

Hasil analisis anova menunjukkan bahwa tipe balok, jenis alat sambung yang tersarang pada tipe, dan diameter alat sambung yang tersarang pada jenis alat sambung tidak berpengaruh nyata $(\mathrm{P}>0.05)$ terhadap nilai MOR. Hal ini menunjukkan kekuatan balok laminasi-mekanik tidak dipengaruhi oleh jenis alat sambung, diameter alat sambung, dan tipe 
balok laminasi. Mardikanto et al. (2011) menyatakan bahwa kekuatan kayu dapat dipengaruhi oleh beberapa faktor diantaranya cacat pada kayu, berat jenis kayu, kadar air, dan zat ekstraktif.

\section{Hubungan beban dan defleksi balok laminasi-mekanik}

Peningkatan beban secara terus-menerus pada balok uji akan mengakibatkan kerusakan. Setiap balok dengan jenis alat sambung, diameter alat sambung, dan tipe balok laminasi memiliki perilaku kerusakan yang berbeda-beda. Gambar 6 menunjukkan kurva hubungan beban dan defleksi balok uji berdasarkan tipe balok hasil pengujian lentur.

Balok glulam memiliki bentuk grafik rata-rata cenderung curam dengan defleksi yang pendek, sedangkan pada balok laminasi-mekanik bentuk grafik yang dimiliki cenderung landai dengan defleksi yang lebih panjang dibandingkan dengan balok glulam. Kemiringan grafik memperlihatkan kekakuan bahan. Mardikanto et al. (2011) menyatakan nilai kemiringan (slope) seirama dengan sifat mudah tidaknya benda tersebut berubah bentuk akibat beban. Semakin kecil slope-nya maka semakin tidak kaku benda tersebut.

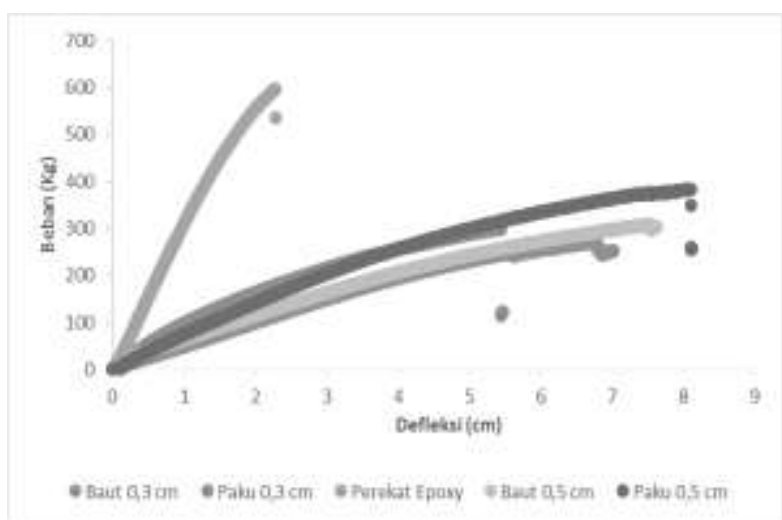

(a)

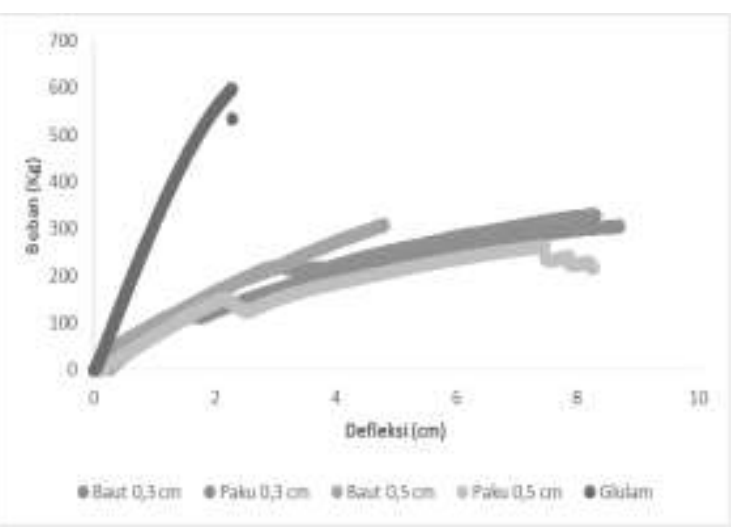

(b)

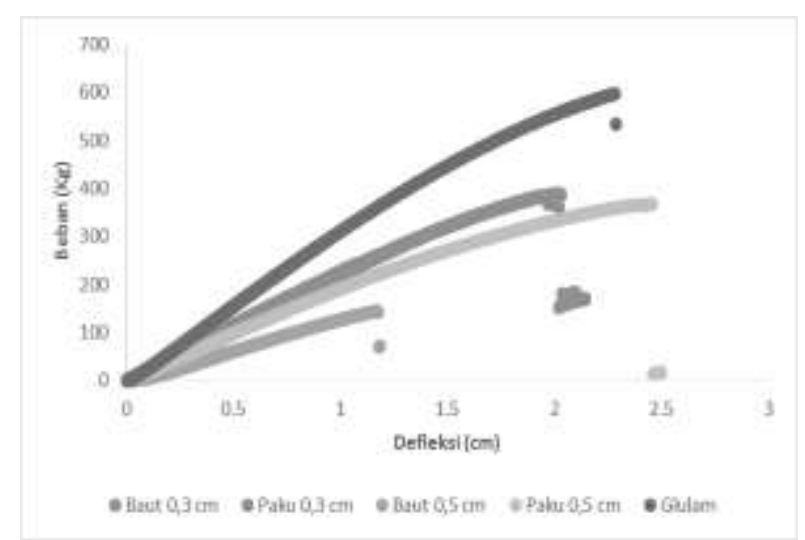

(c)

Gambar 6. Hubungan beban dan defleksi balok uji (a) Tipe 1 (b) Tipe 2 (c) Tipe 3

Sumber: Hasil percobaan/penelitian

Balok glulam memiliki sudut kemiringan grafik (slope) yang lebih besar dibandingkan dengan semua balok laminasi-mekanik tipe 1 (Gambar 6a). Presentase rata-rata kemiringan grafik balok laminasi-paku dimeter $0.3 \mathrm{~cm}$, balok laminasi-paku diameter $0.5 \mathrm{~cm}$, balok laminasi-baut $0.3 \mathrm{~cm}$, dan balok laminasi-baut diameter $0.5 \mathrm{~cm}$ terhadap balok glulam berturut-turut adalah $80.02 \%, 77.26 \%, 79.34 \%$, dan $73.99 \%$. Selain itu balok laminasi-paku diameter 0.3 dan balok laminasi-baut diameter $0.3 \mathrm{~cm}$ memiliki sudut kemiringan yang lebih 
besar dibandingkan balok laminasi-paku diameter $0.5 \mathrm{~cm}$ dan balok laminasi-baut diameter $0.5 \mathrm{~cm}$. Hal ini menunjukkan balok glulam cenderung lebih kaku, sedangkan antar balok lamiansi-mekanik diameter $0.5 \mathrm{~cm}$ pada paku atau baut lebih kaku dibandingkan dengan balok diameter $0.3 \mathrm{~cm}$.

Balok glulam memiliki kemiringan grafik yang lebih besar jika dibandingkan dengan semua balok tipe 2 (Gambar 6b). Presentase rata-rata kemiringan grafik balok tipe 2 pada balok laminasi-paku diameter $0.3 \mathrm{~cm}$, balok laminasi-paku diameter $0.5 \mathrm{~cm}$, balok laminasibaut diameter $0.3 \mathrm{~cm}$, dan balok laminasi-baut diameter $0.5 \mathrm{~cm}$ terhadap balok glulam berturut-turut adalah 71.94\%, 63.19\%, 62.58\%, dan 70.11\%. Berbeda dengan balok tipe 1, pada balok tipe 2 ini presentase kemiringan terbesar terhadap balok glulam adalah balok laminasi-paku diameter $0.3 \mathrm{~cm}$ dan balok laminasi-baut diameter $0.5 \mathrm{~cm}$.

Nilai presentase kemiringan sudut terhadap balok glulam pada balok tipe 2 memiliki nilai yang lebih kecil dibandingkan tipe 1 . Hal ini dipengaruhi oleh penggunaan perekat di bagian tengah balok. Bagian yang menggunakan perekat akan lebih kaku dibandingkan bagian yang menggunakan paku atau baut.

Gambar 6c menunjukkan hubungan beban dan defleksi balok glulam dan balok tipe 3 . Presentase kemiringan rata-rata balok laminasi-paku diameter $0.3 \mathrm{~cm}$, balok laminasi-paku diameter $0.5 \mathrm{~cm}$, balok laminasi-baut $0.3 \mathrm{~cm}$, dan balok laminasi-baut diamater $0.5 \mathrm{~cm}$ tipe 3 berturut-turut adalah $12.62 \%, 27.46 \%, 21.01 \%$, dan $13.04 \%$. Jika dibandingkan balok tipe 1 dan tipe 2, balok tipe 3 memiliki nilai persentase kemiringan terhadap balok glulam yang lebih kecil, sehingga bentuk grafiknya hampir sama dengan balok glulam. Grafik balok tipe 3 cenderung curam dengan defleksi yang rendah. Hal ini diduga karena balok tipe 3 memiliki porsi sambungan perekat yang lebih banyak dibandingkan tipe 2, sehingga kekakuan bahannya lebih tinggi dibandingkan tipe 2 .

Hubungan beban dan defleksi pada balok laminasi-paku disajikan dalam Gambar 7. Tipe 1 pada balok laminasi-paku diameter $0.3 \mathrm{~cm}$ memiliki rata-rata persentase kemiringan terhadap balok glulam tertinggi yaitu $80.02 \%$ dengan defleksi rata-rata $8.54 \mathrm{~cm}$ dan balok laminasi-paku diameter $0.5 \mathrm{~cm}$ sebesar $77.26 \%$ dengan defleksi rata-rata $7.18 \mathrm{~cm}$.

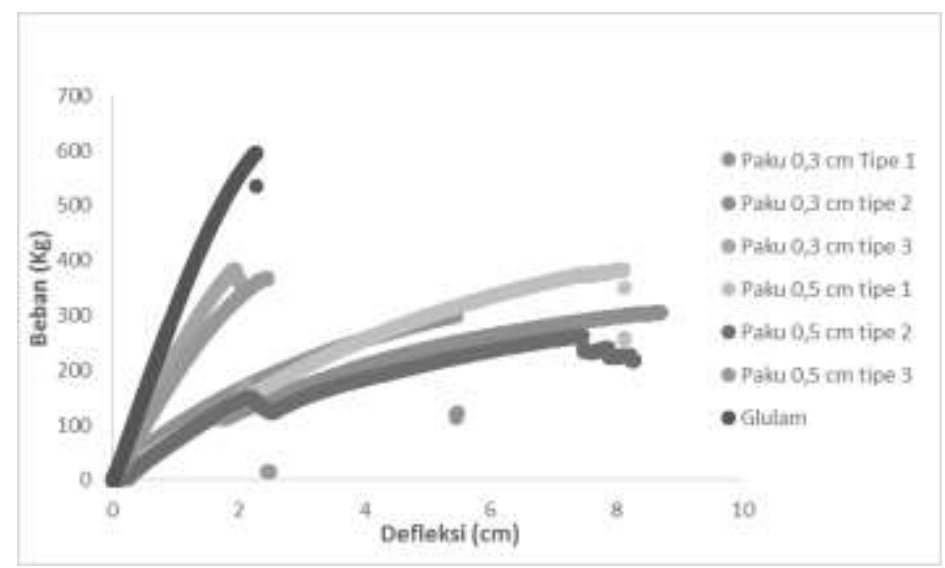

Gambar 7. Hubungan beban dan defleksi balok laminasi-paku Sumber: Hasil percobaan/penelitian

Balok laminasi paku tipe 3 memiliki sudut kemiringan terhadap balok glulam yang kecil (Gambar 7), sehingga bentuk grafiknya cenderung curam dengan defleksi pendek. Balok laminasi-paku diameter $0.3 \mathrm{~cm}$ dan balok laminasi-paku diameter $0.5 \mathrm{~cm}$ memiliki persentase kemiringan terhadap balok glulam berturut-turut $12.62 \%$ dengan defleksi rata-rata $2.30 \mathrm{~cm}$ dan $27.46 \%$ dengan defleksi rata-rata $1.66 \mathrm{~cm}$. Jika sudut kemiringan pada grafik 
dihubungkan dengan kekakuan maka balok laminasi-paku tipe 3 memiliki kekakuan yang terbesar dibandingkan dengan tipe 1 ataupun tipe 2 .

Hubungan beban dan defleksi balok laminasi-baut disajikan pada Gambar 8. Balok laminasi-baut tipe 1 dan tipe 2 memiliki bentuk grafik yang landai dengan defleksi yang panjang. Sedangkan pada tipe 3 bentuk grafiknya cenderung curam dengan defleksi yang pendek. Persentase rata-rata kemiringan grafik terhadap balok glulam tipe 1 balok laminasibaut diameter $0.3 \mathrm{~cm}$ adalah $79.34 \%$ dengan defleksi sebesar $7.50 \mathrm{~cm}$ sedangkan pada balok laminasi-baut diameter $0.5 \mathrm{~cm}$ adalah $73.99 \%$ dengan defleksi sebesar $8.83 \mathrm{~cm}$. Balok laminasi-baut tipe 2 memiliki bentuk grafik yang landai dengan defleksi yang panjang. Namun pada balok tipe 2 ini rata-rata sudut kemiringannya lebih kecil jika dibandingkan dengan tipe 1 .

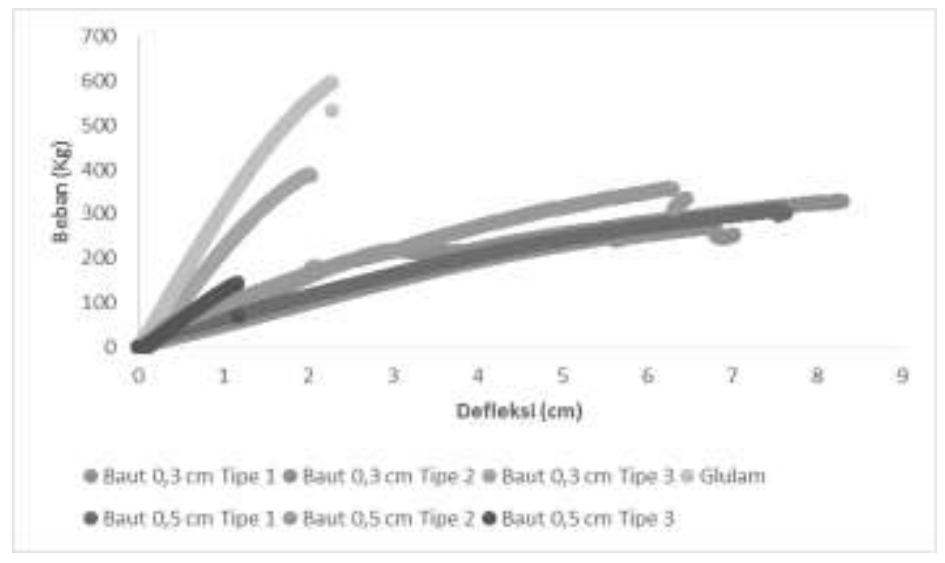

Gambar 8. Hubungan beban dan defleksi balok laminasi-baut Sumber: Hasil percobaan/penelitian

Balok laminasi-baut tipe 3 memiliki nilai persentase rata-rata terhadap balok glulam terkecil jika dibandingkan dengan tipe 1 ataupun tipe 2. Balok tipe 3 pada laminasi-baut diameter $0.3 \mathrm{~cm}$ memiliki rata-rata persentase kemiringan grafik terhadap balok glulam sebesar $21.01 \%$ dengan defleksi $1.64 \mathrm{~cm}$. Sedangkan balok laminasi-baut diameter $0.5 \mathrm{~cm}$ rata-rata prosentase kemiringan grafiknya sebesar $13.04 \%$ dengan defleksi $1.27 \mathrm{~cm}$.

Hasil dari keseluruhan grafik tersebut menunjukkan balok glulam memiliki kekakuan tertinggi dibandingkan balok laminasi-mekanik. Balok laminasi-mekanik tipe 3 pada baut maupun paku memiliki kekakuan yang lebih tinggi jika dibandingkan dengan balok tipe 1 ataupun tipe 2 . Penggunaan perekat sebagai penyambung antar lamina akan mempengaruhi kekakuan balok. Perekat digunakan pada bagian-bagian kayu dan tidak pada titik-titik seperti pada paku atau baut sehingga efisiensi sambungan dengan perekat mencapai $100 \%$ dan menyebabkan kekakuannya lebih tinggi dibandingkan paku atau baut (Yap 1999).

\section{Kerusakan balok laminasi-mekanik}

Hasil pengujian lentur antara balok glulam dan balok kayu laminasi-baut atau balok kayu laminasi-paku memiliki pola keruntuhan yang berbeda. Pada saat pengujian lentur, kerusakan balok glulam terjadi dalam satu tahap. Pemberian beban pada balok glulam mengakibatkan balok mengalami lendutan. Semakin bertambahnya beban, maka kerusakan pada balok glulam semakin terlihat. Saat beban yang diterima sudah maksimum, balok glulam mengalami kerusakan berupa kerusakan lentur di bawah titik pembebanan serta rusaknya lapisan antar lamina (Gambar 9). 
Kerusakan antar lapisan lamina dapat terjadi karena saat pembebanan terjadi gaya tekan dan gaya tarik yang saling berlawanan di garis netral. Pada bagian bawah balok mengalami gaya tarik dan pada bagian atas balok mengalami gaya tekan, sehingga sepanjang garis netral tersebut terjadi geser dan lebih rentan terjadi kerusakan. Penyebab kerusakan pada garis rekat ini adalah kecilnya tekanan yang diberikan saat pengempaan dan waktu kempa. Tekanan kempa akan berpengaruh terhadap ikatan antara perekat dengan kayu antar lamina, sedangkan lama waktu pengempaan akan berpengaruh terhadap pematangan dan penetrasi perekat ke dalam kayu. Widiati (2001) juga mengemukakan bahwa semakin lama waktu kempa maka kemampuan perekat menembus dinding sel semakin besar sehingga pematangan perekat yang terjadi maksimal.

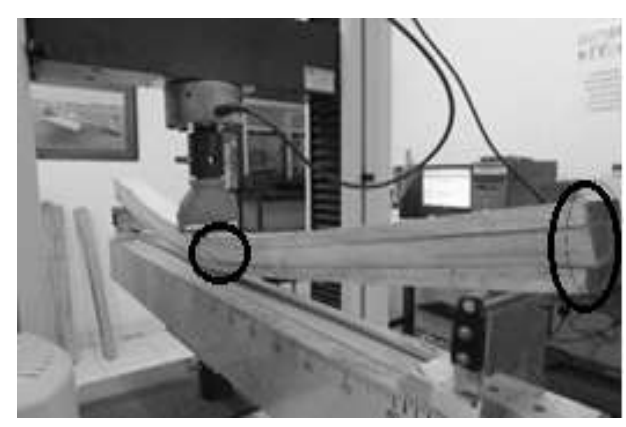

(a)

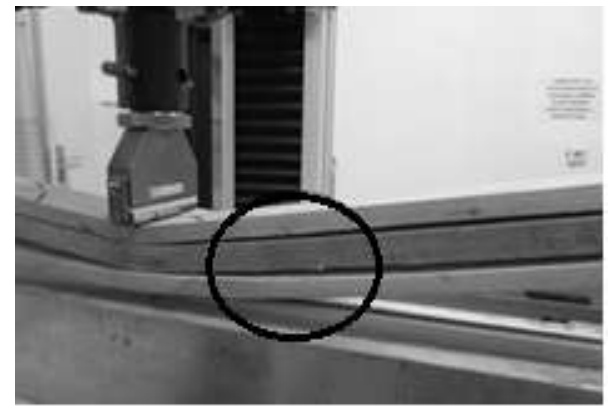

(b)

Gambar 9. Kerusakan balok glulam, (a) di titik pembebanan (b) antar lapisan lamina Sumber: Hasil percobaan/penelitian

Kerusakan yang terjadi pada balok laminasi tipe 1 baik paku ataupun baut menunjukkan pola kerusakan yang hampir sama. Pemberian beban pada balok mengakibatkan balok mengalami lendutan, dengan semakin bertambahnya beban yang diberikan maka akan terjadi kerusakan balok. Kerusakan pada balok ditandai dengan bunyi ledakan. Baik balok laminasi paku ataupun baut tipe keruntuhan yang terjadi seluruhnya berupa keruntuhan lentur (Gambar 10a dan 10b).

Balok tipe 2 laminasi paku ataupun baut memiliki pola kerusakan yang sama. Kerusakan yang terjadi dari balok tipe 2 terdiri dari dua tahap. Saat lendutan semakin besar karena bertambahnya beban, terjadi kerusakan yang dimulai adanya suara seperti ledakan, namun tidak terdapat kerusakan yang tampak pada balok. Kerusakan yang terjadi pada garis rekat lamina terlihat seperti adanya rongga. Kerusakan lentur terjadi ketika beban mencapai maksimum (Gambar 11). Hal tersebut terjadi baik pada balok laminasi-paku maupun balok laminasi-baut dengan dua diameter yang berbeda.

Pada balok tipe 3 baik paku ataupun baut dengan dua diameter yang berbeda menunjukkan pola keruntuhan yang sama. Balok laminasi tipe 3 kerusakan yang terjadi terdiri dari dua tahap. Kerusakan tahap pertama terjadi antar lapisan lamina yang lepas di bagian ujung balok. Selanjutnya dengan semakin bertambahnya beban maka keruntuhan total terjadi dengan lepasnya lapisan antar lamina di ujung serta kerusakan lentur di bagian bawah titik pembebanan (Gambar 12). 


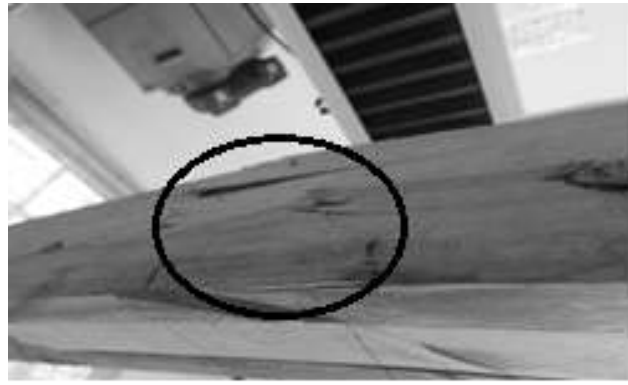

(a)

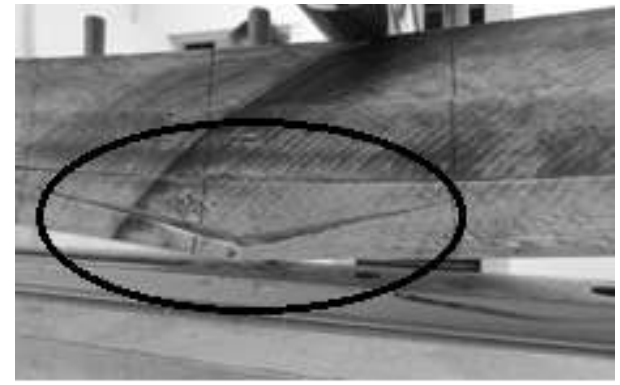

(b)

Gambar 10. Kerusakan lentur, (a) balok laminasi-paku (b) balok laminasi-baut Sumber: Hasil percobaan/penelitian

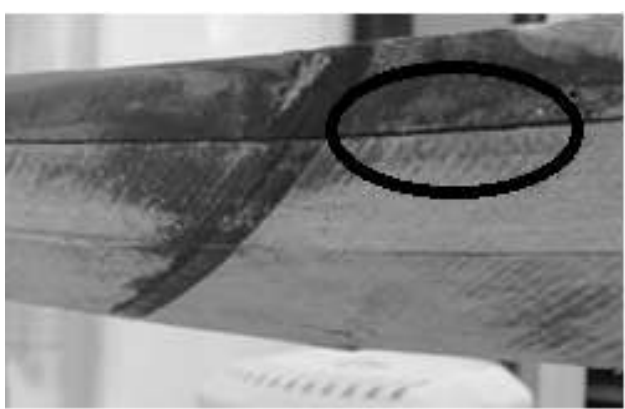

(a)

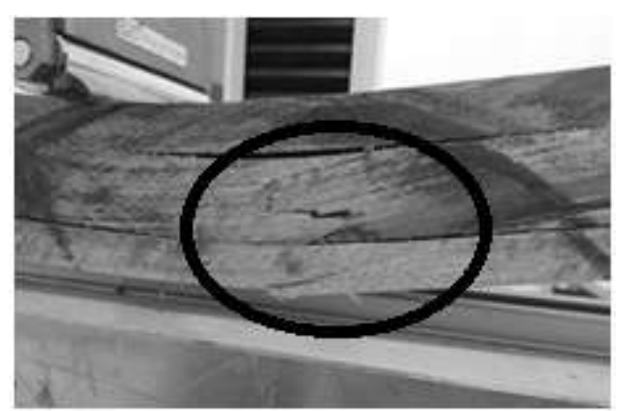

(b)

Gambar 11. Kerusakan pada balok laminasi-paku diameter $0.5 \mathrm{~cm}$ tipe 2

(a) Kerusakan tahap pertama (b) Kerusakan lentur yang terlihat di akhir pengujian Sumber: Hasil percobaan/penelitian

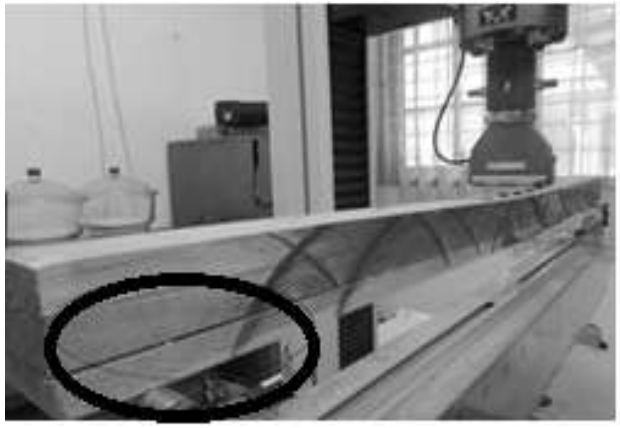

(a)

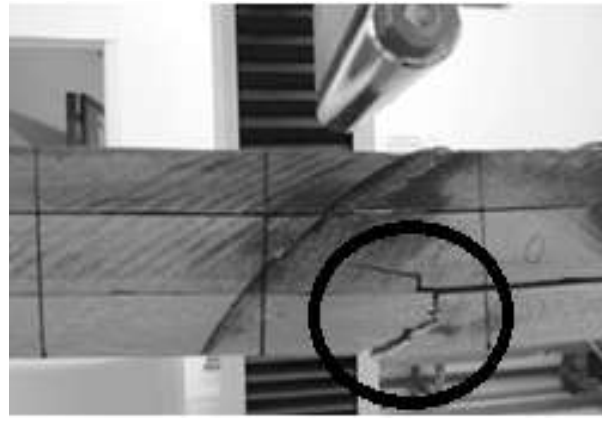

(b)

Gambar 12. Kerusakan pada balok laminasi-paku diameter $0.5 \mathrm{~cm}$ tipe 3

(a) kerusakan tahap pertama (b) kerusakan lentur yang terjadi di akhir pengujian Sumber: Hasil percobaan/penelitian

\section{Kesimpulan dan Saran Kesimpulan}

Berdasarkan hasil penelitian, balok glulam (kontrol) memiliki nilai MOE dan MOR yang paling tinggi dibandingkan semua balok laminasi-mekanik. Balok laminasi tipe 3 memiliki nilai MOE paling tinggi dibandingkan balok tipe 1 dan tipe 2. Nilai MOE balok laminasi tertinggi terdapat pada balok laminasi-paku diameter $0.3 \mathrm{~cm}$ tipe $3(52162.95$ $\mathrm{kg} / \mathrm{cm}^{2}$ ) sedangkan terendah pada balok laminasi-paku diameter $0.3 \mathrm{~cm}$ tipe 1 (11077.41 $\mathrm{kg} / \mathrm{cm}^{2}$ ). Nilai MOR tertinggi adalah balok laminasi-paku diameter 0.3 tipe 3 sebesar $(368.16$ $\left.\mathrm{kg} / \mathrm{cm}^{2}\right)$ serta nilai terendah pada balok laminasi-baut diameter $0.5 \mathrm{~cm}$ tipe 3 sebesar $(207.36$ 
$\mathrm{kg} / \mathrm{cm}^{2}$ ). Posisi penempatan baut, paku, dan perekat pada balok laminasi hanya berpengaruh terhadap nilai MOE. Kerusakan balok laminasi-mekanik semuanya berupa keruntuhan lentur dan kerusakan geser antar lamina.

\section{Saran}

Perlu dilakukan penelitian lebih lanjut mengenai pengujian lentur balok laminasimekanik dengan menggunakan jenis kayu yang berbeda dan variasi besar tekanan pengempaan dan waktu pengempaan untuk perekat epoxy extreme demp-x.

\section{Daftar Pustaka}

Anshari, B (2006). Pengaruh variasi tekanan kempa terhadap kuat lentur kayu laminasi dari kayu meranti dan keruing. Civil Engineering Dimension. 1(8):25-33.

Gere, JM dan Timoshenko, SP (2000). Mekanika Bahan. Suryoatmono B, penerjemah; Hardani W, editor. Jakarta (ID): Penerbit Erlangga. Terjemahan dari: Mechanics of Material Fourth Edition.

[JAS] Japanese Agricultural Standard (2003). Glued Laminated Timber. JAS 234:2003.

Mardikanto, TR., Karlinasari, L., Bahtiar, ET (2011). Sifat Mekanis Kayu. Bogor (ID): IPB Press.

Moody RC., Hernandez, R., Liu, JY (1999). Glued structural members. Di dalam: Wood and Handbook, Wood as Engineering Material. Madison, WI: USDA Forest Service, Forest Product Laboratory.

P3HH (2008). Petunjuk Praktis Sifat-Sifat Dasar Jenis Kayu Indonesia. Indonesia (ID): Indonesian Sawmill and Woodworking Association (ISWA) ITTO Project Pd 286/04.

Sadiyo, S., Wahyudi, I., Yeyet (2011). Pengaruh diameter dan jumlah paku terhadap kekuatan sambungan geser ganda tiga jenis kayu. Jurnal Ilmu dan Teknologi Hasil Hutan. 4(1): 26-32.

Widiati, KY (2001). Pengaruh Tekanan dan Waktu Tekan terhadap Keteguhan Rekat dan Penetrasi Perekat pada Kayu Lamina Prosiding Seminar Nasional IV MAPEKI; 6-9 Agustus 2001; Samarinda (ID).

Yap KHF (1999). Konstruksi Kayu. Bandung (ID): Trimitra Mandiri. 